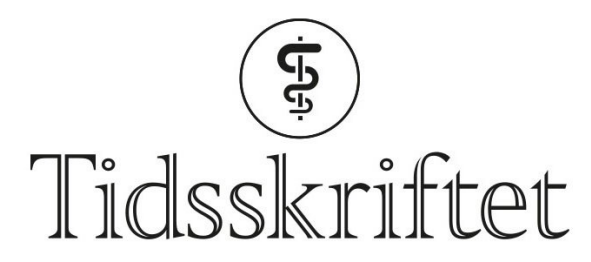

DEN NORSKE LEGEFORENING

\title{
Målebånd for å anslå fødselsvekt og prematuritet
}

FRA ANDRE TIDSSKRIFTER

KRISTOFFER BRODWALL

Barne- og ungdomsklinikken

Haukeland universitetssjukehus

Måling av brystomkrets, overarmsomkrets og fotlengde kan brukes til å anslå lav fødselsvekt og prematuritet i ressursfattige områder av verden.

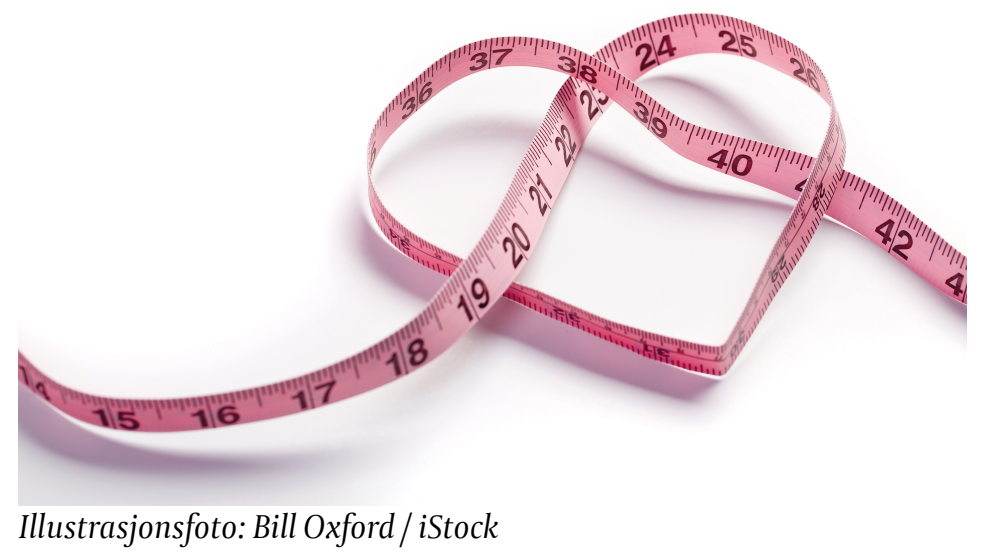

Barnedødeligheten i verden har falt dramatisk det siste århundret, men dødeligheten for nyfødte har man i mindre grad lyktes med å redusere. Over $40 \%$ av dødsfall blant barn under fem år skjer i nyfødtperioden. Prematuritet og lav fødselsvekt er blant de viktigste risikofaktorene for $\mathrm{d} ø \mathrm{~d}$ blant nyfødte, men i mange områder av verden er svangerskapslengde og fødselsvekt ofte ukjent pga. manglende oppfølging av gravide og tilgang på utstyr til å veie nyfødte.

For å fange opp nyfødte som trenger ekstra oppfølging, er det derfor behov for enkle og tilgjengelige metoder for å estimere svangerskapsalder og vekt. I en fersk studie fra Etiopia har man brukt tre målinger til dette formålet (1): Omkrets rundt brystkassen, omkrets rundt overarm og fotbladets lengde. Studien inkluderte nesten 1500 nyfødte barn. Fødselsvekten ble fastslått ved veiing, og svangerskapsalderen ble anslått med to kliniske skåringssystemer for modenhet (The New Ballard score og The Eregie model).

De tre målingene hadde en sensitivitet på 84-92 \% og en spesifisitet på 74-90 \% for å identifisere nyfødte med lav fødselsvekt, dvs. under $2500 \mathrm{~g}$. Til å påvise premature barn, dvs. 
dem med svangerskapslengde under 37 uker, var sensitiviteten $80-86 \%$ og spesifisiteten 63-91\%. Målingen av omkrets rundt brystet hadde best presisjon og er trolig også den målingen som er enklest å utføre riktig. Målingene ble gjort ved 24 timers alder, men for en mindre gruppe ble de gjentatt ved fem dagers alder, med tilsvarende treffsikkerhet. Dette er viktig, ettersom mange nyfødte i Afrika ikke blir sett av helsepersonell før dager etter fødselen.

Flere tidligere studier har gitt lignende funn, men hvor mange $\mathrm{cm}$ som skal brukes som grense for å mistenke lav fødselsvekt eller prematuritet, varierer noe med etnisitet og landtilhørighet.

\section{LITTERATUR:}

1. Gidi NW, Berhane M, Girma T et al. Anthropometric measures that identify premature and low birth weight newborns in Ethiopia: a cross-sectional study with community follow-up. Arch Dis Child 2020; 105:326-31. [PubMed][CrossRef]

Publisert: 24. juni 2020. Tidsskr Nor Legeforen. DOI:10.4045/tidsskr.20.0397

(C) Tidsskrift for Den norske legeforening 2020. Lastet ned fra tidsskriftet.no 